\title{
A Comparative Study on Different Baits Used to Attract House Fly in Malaysia
}

\author{
M. S. Hamid", A. Daud", S. B. Mohamed", N. M. Mohamad", M. A. Rashid" \\ \# FRIT, Universiti Sultan Zainal Abidin, 21300 Kuala Terengganu, Malaysia. \\ E-mail: sobriarie@yahoo.com,alias@unisza.edu.my,saifulbahri@unisza.edu.my;marashid@unisza.edu.my \\ * FBIM, Universiti Sultan Zainal Abidin, 21300 Kuala Terengganu, Malaysia. \\ E-mail:nmm@unisza.edu.my
}

\begin{abstract}
House flies are commonly found at homes and business premises in Malaysia. They are known as vectors of pathogen because they carry the pathogenic bacteria such as Escherichia coli and Salmonella after contacting to animal waste. It is therefore very much essential to control over the house flies so that it cannot be spread out in a large scale. In doing so, many kinds of baits are used to attract and trap these flies either by mechanical or chemical means. But all these baits are not capable of attracting flies equally. The main goal of this study is to find out the best bait that can attract house fly effectively and safely in everyplace. Experiments were conducted to find out the best bait among six different baits commonly used in Malaysia. Two baits made in abroad and four baits made in Malaysia were selected for conducting this study because these baits are commonly used in Malaysia. Experiments were carried out in food industry, fish market and poultry farm in the east coast of Malaysia. Data were collected from the field experiments continuously for six days and analysed to determine the best bait that trap the house flies very effectively. Data analysis results show that the Chinese Electronic Fly Catcher Trap (CEFCT bait is the best one for trapping house flies effectively compared to other baits. Further studies are necessary to find out the low-cost bait components with similar effect of CEFCT bait in local market in order to develop new low-cost bait.
\end{abstract}

Keywords — House fly; Baits; Bottle trap; Bestville.

\section{INTRODUCTION}

The housefly is one of the most common and widespread pest in the world [1], [2]. It can be found in many places like chicken farm, household kitchen, cattle farm, human and animal hospitals, slaughter house and so forth [3]. The major problem created by housefly is that they are very nuisance, irritating human and animals, and leaving some regurgitation and faecal spots on surfaces [4]. They are known as vectors of pathogen because they carry the pathogenic bacteria such as Escherichia coli and Salmonella after contacting to animal waste. Therefore, the house fly cause many serious diseases in human body and animals [5]. In addition, house flies sway farming, ranger service and bring about hypersensitivities through bolstering (gnawing) or by means of inward breath [6]. Literature survey shows that the house fly used to eat at least two to three times a day, and eat all human settlements like milk, sugar, syrup, blood, meat broth and many others [6], [7]. It is therefore very much essential to control over the house fly so that it cannot be spread out in a large scale.
If possible, it is better to destroy the house fly not only in one's home but also in commercial and public areas including animal farms, restaurants, fish market, food processing plant and so many [6]. Monitoring and controlling house flies in such open space is not so easy tasks, rather more challenging than in closed spaces [8]. Sanitation, exclusion along with chemical and non-chemical measures are already been used as the means of controlling house flies [9]. Some cow farmers uses vacuum to trap flies [5], which is non-chemical. Besides, insecticides spray is also used to kill the house fly effectively and is frequently used nowadays to control the house flies [10]. However, all kinds of insecticides spray have very bad effect on health for human and animals. Therefore, researchers are trying to find the safe way to control over the housefly. In doing so, researchers found that baits can be used to attract and trap house fly as the alternative way to control the house fly very effectively. Hence, we decided to study on different baits, which are available and very commonly used in Malaysia.

There are so many kinds of baits commercially available [19][11] in the market in Malaysia, which are used to attract and trap house flies either by chemical or mechanical means. 
But all these commercial baits are not capable of attracting flies equally because of component combined don't have equally sensitive smell [12]. It is of great importance then to determine the best bait so that people can use that one to attract and trap house fly effectively. In order to find the best bait, authors studied extensively on six different baits which are available in the local market and frequently used in Malaysia.

Authors surveyed the local market and selected two baits, namely Bestville bait and Chinese Electronic Fly Catcher Trap (CEFCT) bait which are made in abroad [13]. Authors also selected four local baits, namely shrimp paste, anchovy sauce, fish stomach and palm sugar for conducting this study. Authors conducted experiments using six selected baits in Food industry, Fish market and Poultry farm in the east coast of Malaysia. Experimental data were analysed to determine the best bait among all selected baits that trap the house fly very effectively. Authors also determine the duration of time period for which the selected best bait is useful in trapping house fly in every place effectively.

\section{MATERIAL AND METHOD}

In this study, a simple bottle trap technique as shown in Fig. 1 is used to conduct the field experiments for testing all types of selected baits. This simple and low cost trap (cylinder-shape, $15 \mathrm{~cm}$ height and $2.5 \mathrm{~cm}$ radius, Fig. 1) is used to assess the attractiveness of the baits. All parts of this trap are made from the plastic materials. Baits were placed on the bottom of the bottle as shown in Fig.1. In total 18 bottle traps were used in three different experimental locations in the east coast of Malaysia. In every location, six traps with six different baits are used for conducting experiments six days continuously.
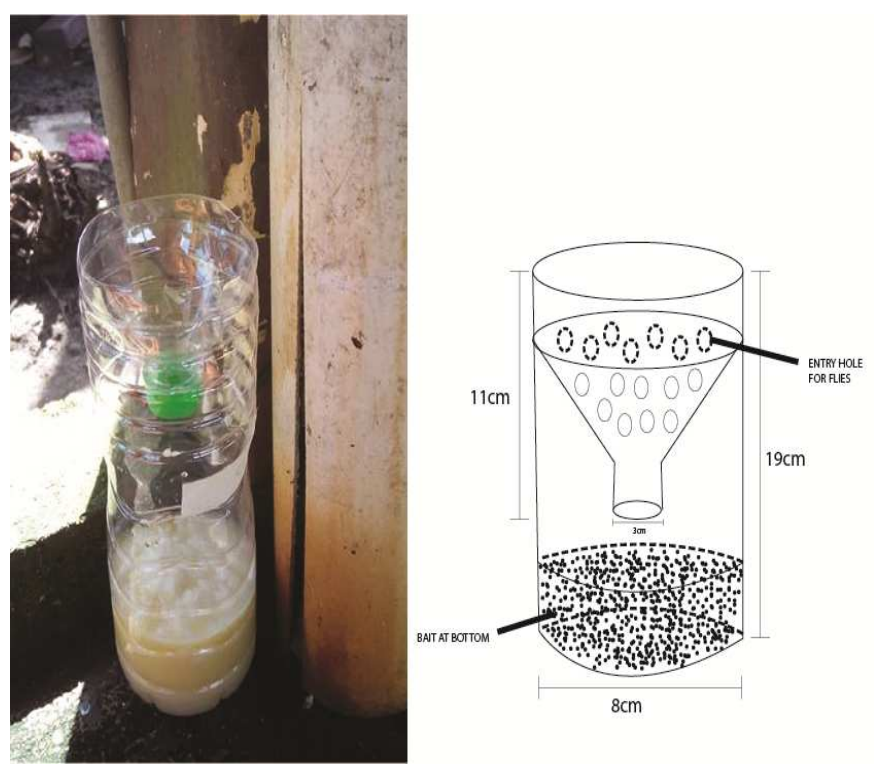

Fig. 1 A schematic of bottle trap to catch flies in the field experiments.

\section{A. Location Selection for Experiments}

In this study, we select three different industries situated in three different locations in the east coast of Malaysia. The first field experiment was conducted in Food processing industries (Keropok Lekor Istimewa Sri Tanjung, Kampung Sri Tanjung, Batu Rakit, Kuala Terengganu, Terengganu, Malaysia). The second field experiment was conducted in Poultry farm (Ladang Bari, Setiu, Terengganu, Malaysia). The third and last experiment was conducted in the Fish market (Pasar Pekan Batu 6, Kuala Terengganu, Terengganu, Malaysia).

\section{B. Sample Preparation for Experiments}

Six types of sample solution were prepared for six different baits used in the field experiments, which are shown in Fig.2. The first commercial bait (Bestville bait) that made in abroad and consists of $25 \%$ of granulated sugar, $25 \%$ of baking powder, $25 \%$ of honey, and $25 \%$ of water (Solution A). The second commercial bait (CEFCT bait), which also made in abroad and consists of $80 \%$ powder solution and $20 \%$ molasses (Solution B). The first local made bait called the anchovy sauce bait consists of $80 \%$ budu and $20 \%$ of molasses (Solution C). The second local bait is fish stomach bait that consists of $80 \%$ fish of stomach and $20 \%$ of molasses (Solution D). The third is shrimp paste bait consisting of $80 \%$ shrimp paste (belacan) and $20 \%$ molasses (Solution E). And the fourth is brown sugar bait that consist of $80 \%$ of palm sugar and $20 \%$ of molasses (Solution F).
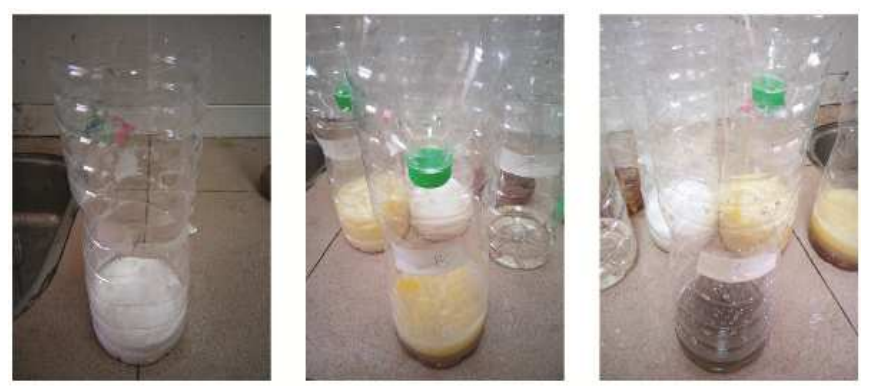

SOLUTION (A)

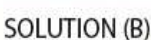

SOLUTION (C)

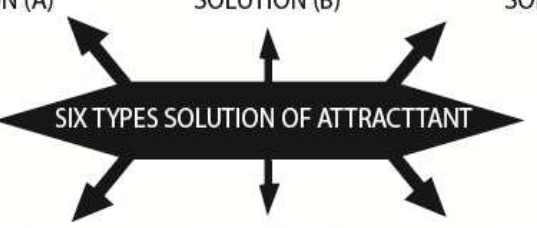

SOLUTION (D)

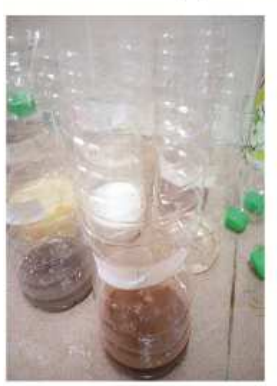

SOLUTION (E)

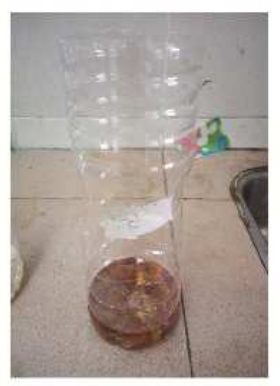

SOLUTION (F)

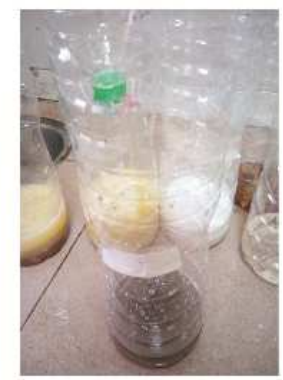

Fig. 2 Six types of bait solutions used in experiments.

\section{Placement of Traps in Experiments}

We have conducted field experiments on six different baits in the poultry farm, fish market and food processing industries in the east coast of Malaysia. The experimental setup including traps and attractant (bait) are placed according to the arrangement as shown in Fig.3. The trap 
positions were rotated daily from the position $\mathrm{A}$ to $\mathrm{F}$ according to Fig.3. This rotation was done in order to minimize the positional effect on trapping flies during the experiment. Experiments were carried out from 8.00 a.m. to 6.00 p.m. daily. The trapped flies were counted for each bottle trap on a regular basis every day. Each combination was run simultaneously and independently for six times for a total of six replications.

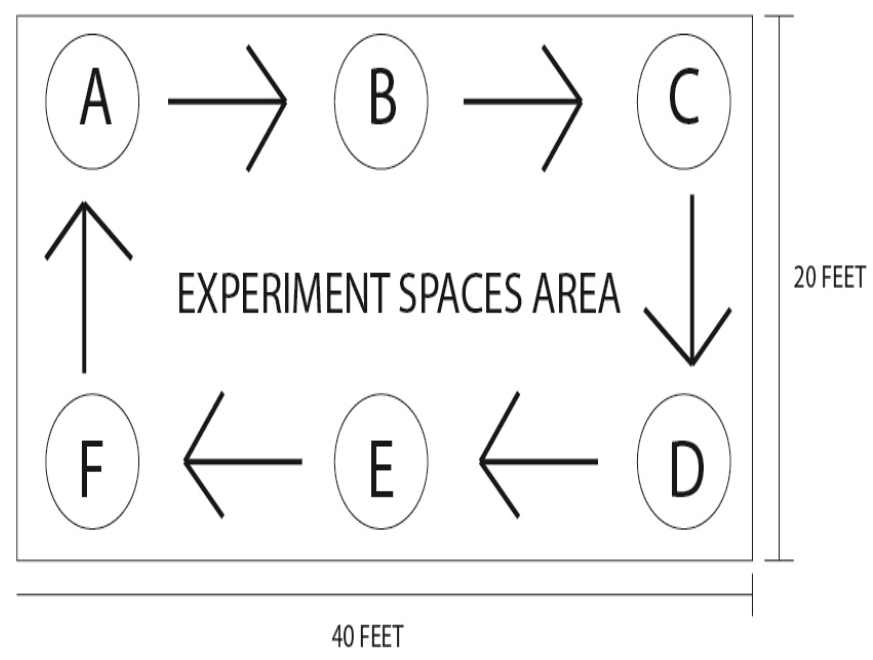

Fig. 3 Arrangement of experimental setup including traps and bait in Poultry farm, Fish market and Food industries.

\section{Reasons for Selecting Poultry farm, Fish market \& Food processing industries}

We have done field survey in order to find suitable place in Terengganu, east coast of Malaysia, for conducting our field experiments. After carful observation, we found that the Poultry farm, Fish market \& Food processing industries are suffering from flies largely. The existence of flies are available all time regardless of seasons and weather conditions. We have therefore selected these three industries, Poultry farm, Fish market \& Food processing industries, Poultry farm, Fish market \& Food processing industries, for conducting our field trial. We also make sure that all these three industries have sufficient physical space for the arrangement of experimental set up including traps and bait according to Fig.3.

\section{E. Data Collection from Experiments}

Experiments were conducted on six different baits for six days in poultry farm, food processing industries and fish market. The numbers of flies trapped in each trap were collected every day. Then all collected flies were counted every day for each traps starting from day 1 until the day six. We collected data continuously for six days. The details of data collected from different field experiments are recorded data are shown in Table I, Table II and Table III. The date of experiment and the type of traps used are clearly written in the data table.

\section{1) Data from Poultry Farm}

Experiments were conducted in Poultry farm for six days starting from December 20, 2015 to December 26, 2015 in Terengganu state, the east coast of Malaysia. Table I shows the details of data recorded from the experiments conducted in Poultry farm for six days.

\section{2) Data from Fish Market}

Experiments were conducted in the Fish market for the period from Dec 27, 2015 to Jan 1, 2016 in the Terengganu state of Malaysia. Table II shows the collected data for six days for six different baits used in the experiments.

\section{3) Data from Food Processing Industries}

Experiments were carried out for six days continuously from January 2, 2015 to January 7, 2016 in food processing industries in Terengganu state of Malaysia. Table III show the details of data obtained from the experiment on six different baits for six days.

TABLE I

EXPERIMENTAL DATA FROM POULTRY FARM

\begin{tabular}{|l|c|c|c|c|c|c|c|}
\hline \multicolumn{7}{|c|}{ Poultry Farm } \\
\hline \multicolumn{1}{|c|}{ Bait / Days } & $\mathbf{1}$ & $\mathbf{2}$ & $\mathbf{3}$ & $\mathbf{4}$ & $\mathbf{5}$ & $\mathbf{6}$ & Total \\
\hline $\begin{array}{l}\text { Bestville bait + } \\
\text { Molasses }\end{array}$ & 3 & 3 & 9 & 9 & 18 & 27 & 69 \\
\hline $\begin{array}{l}\text { Chinese Electronic Fly } \\
\text { Catcher Bait (CEFCT) } \\
+ \text { Molasses }\end{array}$ & 9 & 3 & 21 & 21 & 36 & 45 & 135 \\
\hline $\begin{array}{l}\text { Anchovy Sauce + } \\
\text { Molasses }\end{array}$ & 3 & 5 & 3 & 3 & 3 & 3 & 20 \\
\hline $\begin{array}{l}\text { Fish Stomarch + } \\
\text { Molasses }\end{array}$ & 3 & 3 & 1 & 3 & 1 & 1 & 12 \\
\hline $\begin{array}{l}\text { Shrimp Paste + } \\
\text { Molasses }\end{array}$ & 3 & 9 & 9 & 18 & 24 & 34 & 97 \\
\hline Palm Sugar + Molasses & 1 & 1 & 3 & 3 & 0 & 1 & 9 \\
\hline
\end{tabular}

TABLE II

EXPERIMENTAL DATA FROM FISH MARKET

\begin{tabular}{|l|c|c|c|c|c|c|c|}
\hline \multicolumn{7}{|c|}{ Fish Market } \\
\hline \multicolumn{1}{|c|}{ Bait / Days } & $\mathbf{1}$ & $\mathbf{2}$ & $\mathbf{3}$ & $\mathbf{4}$ & $\mathbf{5}$ & $\mathbf{6}$ & Total \\
\hline $\begin{array}{l}\text { Bestville bait + } \\
\text { Molasses }\end{array}$ & 6 & 6 & 13 & 9 & 18 & 20 & 72 \\
\hline $\begin{array}{l}\text { Chinese Electronic } \\
\begin{array}{l}\text { Fly Catcher Bait } \\
\text { (CEFCT) + } \\
\text { Molasses }\end{array}\end{array}$ & 6 & 9 & 18 & 22 & 25 & 30 & 110 \\
\hline $\begin{array}{l}\text { Anchovy Sauce + } \\
\text { Molasses }\end{array}$ & 2 & 6 & 2 & 2 & 0 & 2 & 14 \\
\hline $\begin{array}{l}\text { Fish Stomarch + } \\
\text { Molasses }\end{array}$ & 2 & 0 & 1 & 2 & 4 & 3 & 12 \\
\hline $\begin{array}{l}\text { Shrimp Paste + } \\
\text { Molasses }\end{array}$ & 2 & 8 & 15 & 18 & 20 & 24 & 87 \\
\hline $\begin{array}{l}\text { Palm Sugar + } \\
\text { Molasses }\end{array}$ & 1 & 1 & 0 & 1 & 0 & 1 & 4 \\
\hline
\end{tabular}


TABLE III

EXPERIMENTAL DATA FROM FOOD PROCESSING INDUSTRIES

\begin{tabular}{|l|c|c|c|c|c|c|c|}
\hline \multicolumn{7}{|c|}{ Food Processing Industries } \\
\hline \multicolumn{1}{|c|}{ Bait / Days } & $\mathbf{1}$ & $\mathbf{2}$ & $\mathbf{3}$ & $\mathbf{4}$ & $\mathbf{5}$ & $\mathbf{6}$ & Total \\
\hline $\begin{array}{l}\text { Bestville bait + } \\
\text { Molasses }\end{array}$ & 1 & 1 & 3 & 3 & 6 & 9 & 23 \\
\hline $\begin{array}{l}\text { Chinese Electronic Fly } \\
\text { Catcher Bait (CEFCT) } \\
\text { + Molasses }\end{array}$ & 3 & 1 & 6 & 6 & 12 & 15 & 43 \\
\hline $\begin{array}{l}\text { Anchovy Sauce + } \\
\text { Molasses }\end{array}$ & 1 & 3 & 1 & 1 & 1 & 1 & 23 \\
\hline $\begin{array}{l}\text { Fish Stomarch + } \\
\text { Molasses }\end{array}$ & 1 & 1 & 0 & 1 & 1 & 0 & 4 \\
\hline $\begin{array}{l}\text { Shrimp Paste + } \\
\text { Molasses }\end{array}$ & 0 & 0 & 1 & 1 & 0 & 1 & 3 \\
\hline $\begin{array}{l}\text { Palm Sugar + } \\
\text { Molasses }\end{array}$ & 1 & 4 & 4 & 8 & 12 & 32 \\
\hline
\end{tabular}

\section{RESULT AND DISCUSSION}

This section presents the result of data analysis using the data obtained from the field trial in a Chicken farm, Food industries and Fish market in Terengganu, which is the east coast of Malaysia. The trapping capacity of six different baits were used to determine the best and effective bait based on the number of flies trapped in each bait.

Fig. 4 shows the the number of flies trapped in each bait for six different days. It is clearly seen from Fig.4 that the CEFCT bait catches more flies compared to other baits every day except the day 2. It is also seen in Fig.4 that the number of trapped flies by CEFCT bait increases gradually from day 2 to day 6 . It seems that the day 5 and the day 6 are the days when the CEFCT is more effective than other days comparatively. This experimental result can reveal that the CEFCT bait is the best and most effective bait for trapping flies in Poultry farm if the performance on day 2 is ignored.
Fig. 5 highlights the result of data analysis regarding experiments conducted for six baits in the Fish market. If we take a look at Fig. 5 then we can observe that the number of flies caught by CEFCT bait from the day 1 to day 6 are increased continuously and highest in number compared to other baits except for the day 1 . The number of flies caught by CEFCT and Bestville bait in day 1 is equal. On average, the performance of CEFCT bait in terms of trapping flies is much better than other baits based on the evidence as seen from Fig.5 for the Fish market. It can be concluded that CEFCT bait is that bait which can catch more flies in the Fish market compared to other baits.

Similar in Figs. 4 and 5, the Fig. 6 shows the comparison of flies trapped by six different baits for 6 days. From the results in Fig.6, we can conclude that CEFCT bait catches the highest number of flies for everyday experiment in the Food processing industries except for the day 2. The performance of CEFCT bait is very good for the most of the days. It seems the CEFCT bait can be considered as the effective one for the food processing industries compared to other bats used in this study.

Fig. 7 shows the mean captures of house flies for six days for six different baits from the Chicken farm, Fish market and Food processing industries. It is very clear from Fig. 7 that the total number of flies caught by CEFCT bait is the highest in number compared to any other baits considered in this study. Based on all results as discussed above, we can claim that the Chinese Electronic Fly Catcher Trap (CEFCT) bait is the best bait and proven to be the most effective bait for trapping house fly in Poultry farm, Fish market and Food processing industries.

The author also found through bioassays analysis (not shown here) that CEFCT bait is very effective for the first two hours duration of time.

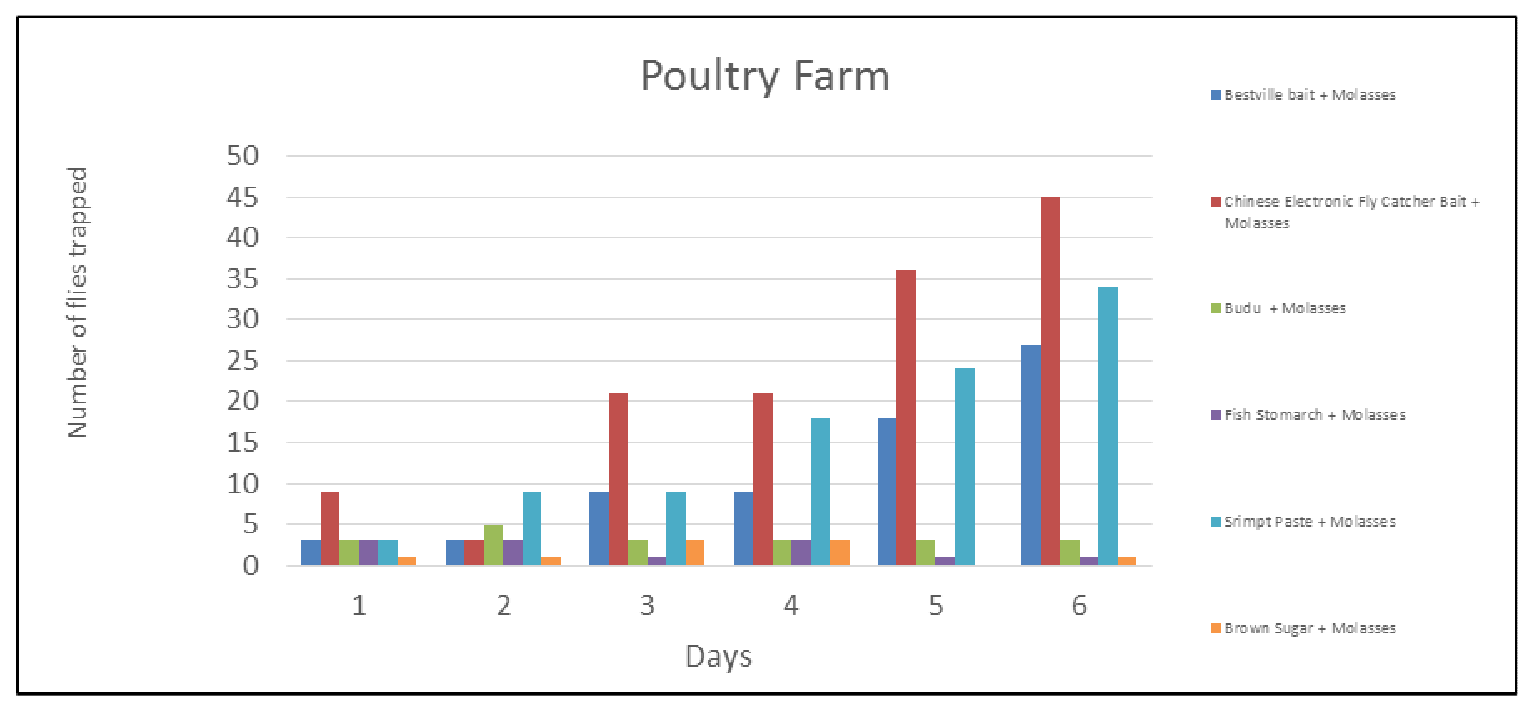

Fig. 4 Number of flies trapped from day 1 to day 6 at Poultry Farm 


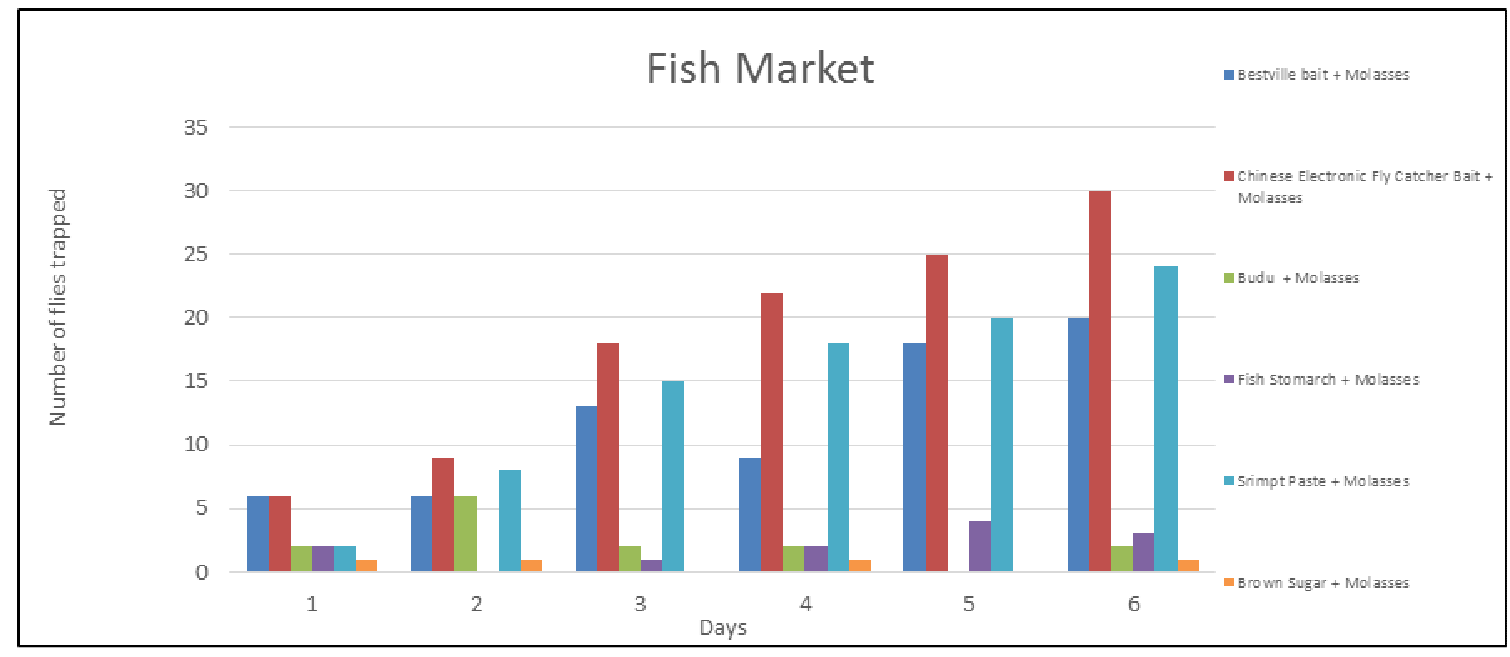

Fig. 5 Number of flies trapped from day 1 to day 6 at Fish Market.

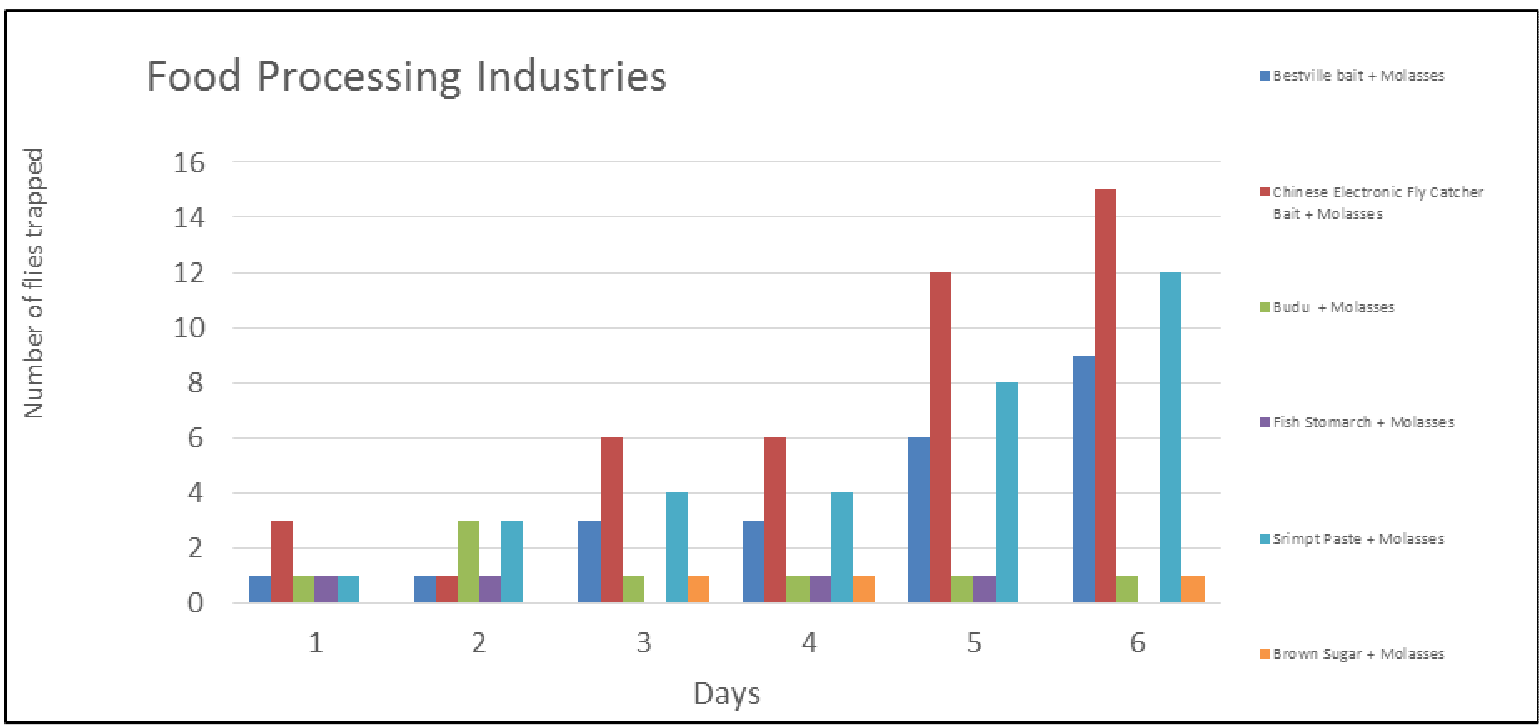

Fig. 6 Number of flies trapped from day 1 to day 6 at Food Processing Industries

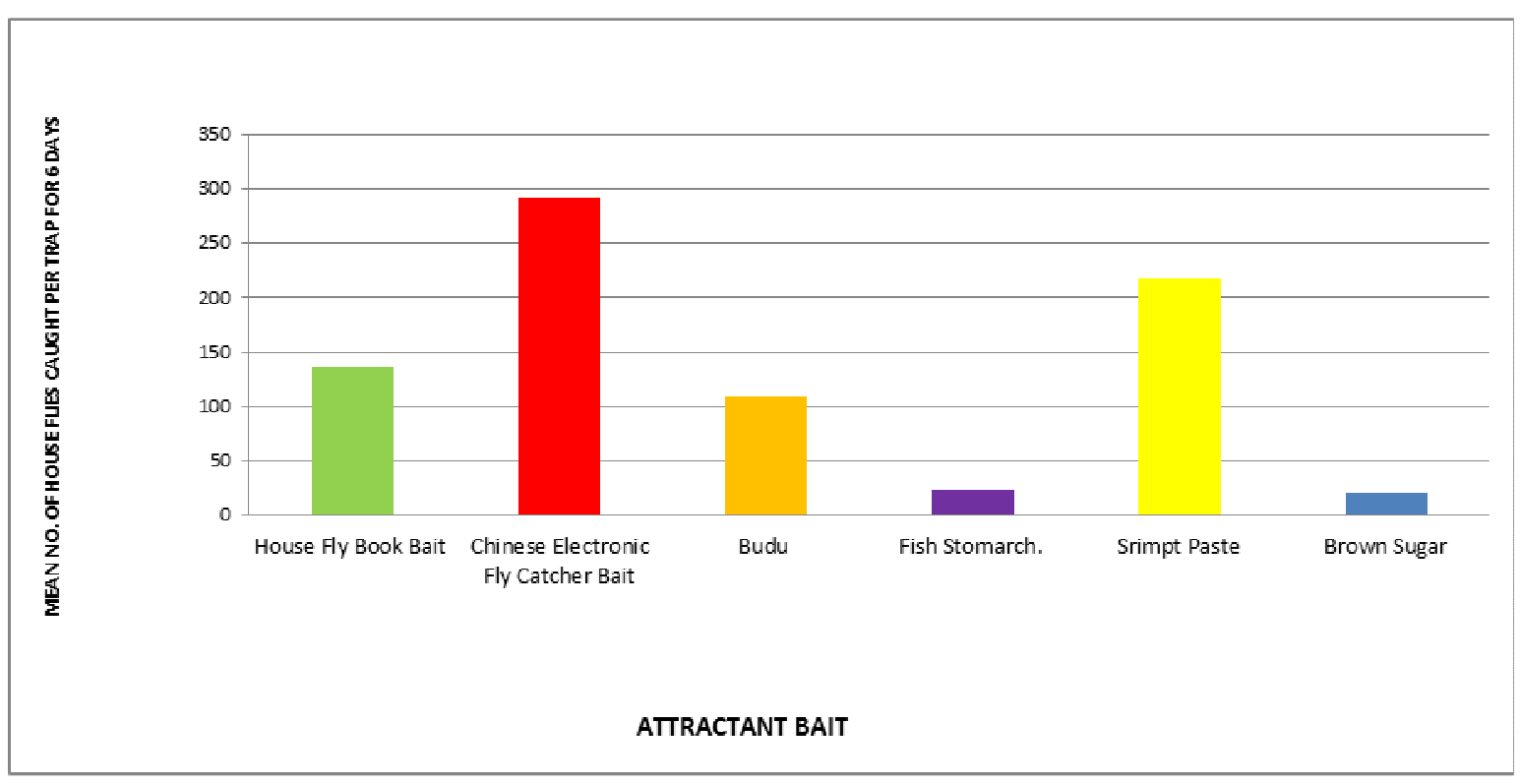

Fig. 7 Mean captures of house flies for six days by different baits from chicken farm, fish market, and food industries. 


\section{CONCLUSIONS}

Authors conducted a comparative study on six different baits which available in the local market and commonly used to attract house fly in Malaysia. Authors conducted field experiments on these six different baits in different environment like in Poultry farm, Fish market and Food processing industries in the Terengganu state of Malaysia. Based on the results from all experiments, authors found that all the commercial baits have no equal ability to attract and trap house flies effectively. Among six baits used in this this study, the Chinese Electronic Fly Catcher Trap (CEFCT) bait is the best bait, because it has the highest ability to attract house flies compared to other baits, and this was probably due to a number of design factors including whether. It was also observed that that CEFCT bait is very effective for the first two hours duration of time in use. The performance of attracting and trapping house fly decrees after the use of 2 days.

Further studies are necessary to find the low-cost bait components with similar effect of the best bait (CEFCT) in local market in order to develop a new low-cost bait. To identify the active compound of the CEFCT bait, volatile analysis of CEFCT bait can be done.

\section{ACKNOWLEDGMENT}

The authors would like to express an appreciation to the East Coast Environmental Research Institute (ESERI), Faculty of Biotechnologies and Food Industries, and Faculty of Medicine, Universiti Sultan Zainal Abidin (UniSZA) for giving advice, guidance, and their research laboratory facilities. Authors also would like to acknowledge a great support for laboratory task from Pn. Rokiah binti Zainuddin, Wan Nor Fatihah binti Wan Mohamad and Mr. Malik for this project.

\section{REFERENCES}

[1] Stensmyr and M. C, The Natural History and Diversity of Diptera, vol. 23 , no. 8.2013

[2] House Fly. (2016). EOL community homepage [Online], Available: http://eol.org/pages/730039/details

[3] R. Ranjbar, M. Izadi, T. T. Hafshejani, and F. Khamesipour, "Molecular detection and antimicrobial resistance of Klebsiella pneumoniae from house flies (Musca domestica) in kitchens, farms, hospitals and slaughterhouses.," J. Infect. Public Health, 2016.

[4] V. J. Cirillo, "I Am the Baby Killer!' House Flies and the Spread of Polio.," Am. Entomol., vol. 62(2), no. Rogers, pp. 83-85, 2016.

[5] S. S. Denning, S. P. Washburn, and D. W. Watson, "Development of a novel walk-through fly trap for the control of horn flies and other pests on pastured dairy cows," J. Dairy Sci., vol. 97, no. 7, pp. 46244631, 2014.

[6] G. W. Courtney and P. S. Cranston, Order Diptera, Fourth Edi. Elsevier, 2015.

[7] Carter and B Danny, "Fly Trap And Bait Therefor," Washington, DC U.S. Pat. Trademark Off., vol. 2, no. 12, 2004.

[8] C. J. Geden, "Methods for monitoring outdoor populations of house flies , Musca domestica L . ( Diptera : Muscidae )," J. Vector Ecol., vol. 30 (2), no. December, pp. 244-250, 2005.

[9] Rozendaal, J. A., D. A. Dame, and A. Brammer, "Public-health Pesticide Applicator Training Manual: University of Florida, Institute of Food and Agricultural Sciences.," in Institute of, \& Sciences, Agricultural., no. house flies, 2011, pp. 312-313.

[10] E. T. Machtinger, E. N. I. Weeks, C. J. Geden, and P. E. Kaufman, "House fly ( Musca domestica ) (Diptera: Muscidae) mortality after exposure to commercial fungal formulations in a sugar bait," Biocontrol Sci. Technol., vol. 3157, no. August, pp. 1-13, 2016.

[11] J. W. D. Ii, J. C. Hertz, R. M. Welch, P. G. Koehler, and R. M. Pereira, "( Diptera- Muscidae ) and Reduce Annoyance," no. September 2011, pp. 56-64, 2012.

[12] T. S. Davis, T. L. Crippen, R. W. Hofstetter, and J. K. Tomberlin, "Microbial Volatile Emissions as Insect Semiochemicals," J. Chem. Ecol., vol. 39, no. 7, pp. 840-859, 2013.

[13] L. G. Pickens, E. T. Schmidtmann, and and R. W. Miller, How To Control House and Stable Flies Without Using Pesticides. 1997. 